\title{
A Systematic Analysis of Studies on Corona Virus Disease 19 (COVID-19) from Viral Emergence to Treatment
}

\author{
Shahzadi Misbah ${ }^{1}$, Abrar Ahmad ${ }^{1}$, Muhammad Hammad Butt ${ }^{1}$, Yusra Habib Khan², Nasser Hadal Alotaibi ${ }^{2}$ and \\ Tauqeer Hussain Mallhi \\ ${ }^{1}$ Faculty of Pharmacy, University of Central Punjab, Lahore, Pakistan \\ ${ }^{2}$ Department of Clinical Pharmacy, College of Pharmacy, Jouf University, Sakaka, Al-Jouf Province, Kingdom of Saudi Arabia
}

\begin{abstract}
Severe acute respiratory syndrome coronavirus 2 (SARS-CoV-2) has created tremendous panic around the globe amid rapid transmission and high mortality. The virus emerged from China in December 2019 and spread to over 200 countries. The number of cases in USA and Europe has surpassed that of China. Epidemiologists believe that more cases and deaths may occur till undefined time period. During the current health crisis when scientific community is battling hard to contain the COVID-19, provision of timely and authenticative information in a composite document based on recent findings carries substantial value. To the best of authors' knowledge, there is no comprehensive review on COVID-19 till date. In this context, current manuscript is aimed to provide amalgamated information in a single document to healthcare professionals, researchers and the general public regarding the outbreak-turned-pandemic of COVID-19. This systematic review discusses epidemiology, pathogenesis, transmission, clinical manifestations, severity, treatment, prevention, vaccination, medication repositioning, potential drug candidates, and control and public awareness of COVID-19.
\end{abstract}

Key Words: COVID-19, Pandemic, Epidemiology, Virology, SARS-CoV-2, World Health Organization, Corona Virus.

How to cite this article: Misbah S, Ahmad A, Butt MH, Khan YH, Alotaibi NH, Mallhi TH. A Systematic Analysis of Studies on Corona Virus Disease 19 (COVID-19) from Viral Emergence to Treatment. J Coll Physicians Surg Pak 2020; 30(JCPSPCR):CR9-CR18 https://doi.org/10.29271/jcpsp.2020.JCPSPCR.CR9.

\section{INTRODUCTION}

Coronaviruses belong to family coronaviridae with well-structured envelopes and plus-strand RNA. Numerous species of this family have been involved in various infections. The pathogenicity of these viruses is not limited to humans only, but has also extended to animals including bats, rats, cattle, rabbits, dogs, swines, chickens, cats, turkeys, mice and horses. Table (I) describes the details of some important viruses of this family. Viral contract results in various respiratory and digestive disorders. The discovery of HCoV-OV43 and HCoV-229E dated back to 60 's and have been recently known to cause common cold. ${ }^{1,2}$ Previously, these viruses were known to cause mild to moderate infection in humans and were not considered as highly pathogenic, until the Severe Acute Respiratory Syndrome (SARS) outbreak emerged in China during 2003 and 2004. In 2012, another outbreak by a highly pathogenic virus named MERSCoV (Middle East Respiratory Syndrome Coronavirus) was reported in Saudi Arabia. ${ }^{3}$ In 2019, when Middle Eastern countries

Correspondence to: Dr. Tauqeer Hussain Mallhi, Department of Clinical Pharmacy, College of Pharmacy, Jouf University, Sakaka, Al-Jouf Province, Kingdom of Saudi Arabia

E-mail: tauqeer.hussain.mallhi@hotmail.com

Received: April 28, 2020; Revised: June 02, 2020;

Accepted: June 17, 2020

DOI: https://doi.org/10.29271/jcpsp.2020.JCPSPCR.CR9 were putting their efforts to combat the MERS, another novel coronavirus SARS-CoV-2 emerged in Wuhan, China (Figure 1). World Health Organization (WHO) coined the name of COVID-19 following its rapid spread to the other countries and declared it pandemic. Scientific communities around the globe are battling hard to provide scientific evidences related to COVID-19 in order to curb the growing encumbrance of the infection.

To the best of authors' knowledge, there is no composite document with comprehensive information of infection and virus till the uniting of this manuscript. Keeping in view the overwhelmed healthcare system and extensive burden on health professionals, timely and authenticative information carries substantial value. In this context, a comprehensive draft on recent findings will be of paramount importance and may aid to extract useful information during limited time.

The aim of the current manuscript was to provide a systematic review of recent findings on the virus structure and genome, modes of transmission, disease epidemiology, clinical manifestations, diagnosis, complications, management, and public awareness and response.

\section{SEARCH METHODOLOGY:}

This current review included the recent advances in the research of COVID-19 to provide precise and comprehensive information on several aspects ranging from emergence of virus to treatment and prevention. All the required information were collected via an electronic search of different scientific 
sources including PubMed (http://www.ncbi.nlm.nih.gov/pubmed), Science Direct (http://www.scopus.com/), Google Scholar (http://scholar.google.com/), Scientific Electronic Library Online (SciELO) (http://www.scielo.org/), Cochrane library (http:// www.cochranelibrary.com/), and Web of Science (http://www.webofknowledge.com/). The study data-base encompassed articles of peer-reviewed journals, books, thesis, dissertations, various patents and supplementary reports covering all aspects of COVID-19 from date of inception to May 2020. Since many updates on COVID-19 are also distributed through news, current review also included these sources if scholarly paper was not found.

Authors opted the following keywords to find the relevantstudies:

\section{SARS-CoV-2 Structure}

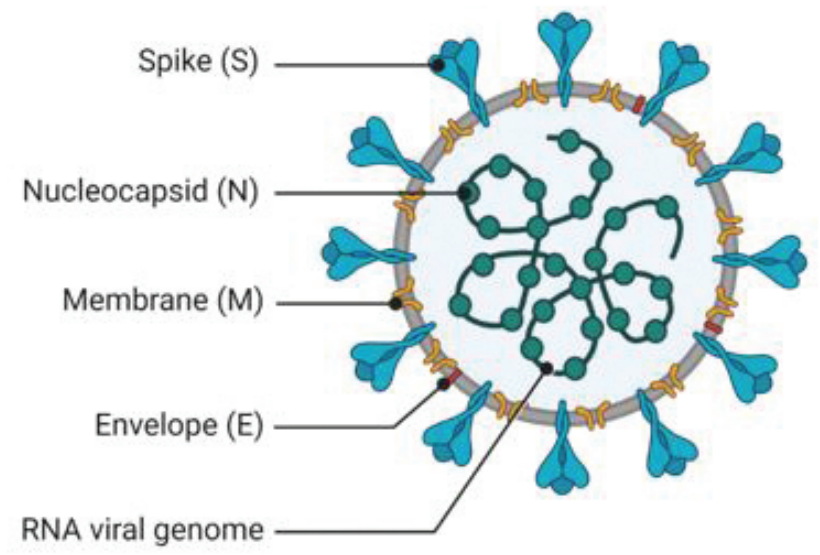

Figure 1: Structure of SARS-CoV-2.

Corona Virus, Corona Virus Disease, COVID-19, SARS, novel Corona Virus, nCoV, Corona Infection, Wuhan Coron, SARS-CoV-2, FDA, World Health Organization, Centre for Disease Control and Prevention, Treatment and Prevention, Vaccination, Chloroquine, Hydroxychloroquine, Virus replication, Clinical Manifestation, Complications, Drug Repurposing Social distancing, sanitizer, Ivermectin, Disinfectant, COVID-19 mortality, Pneumonia, Acute respiratory distress syndrome, pulmonary disease. These terms were either used alone or in combination by using Boolean operators (and, or, not).

The studies related to the disease history, transmission, management, diagnosis, complications, treatment, prevention and outcomes were selected and subjected to critical review. Furthermore, the papers analysing the efficacy of various medicines against COVID-19 were also included. With the information assembled through these studies, the actual summary of various aspects of COVID-19 were pointed out. Since all the studies were recent and authenticated, they were included in to the review without quality scoring. The primary reason of not performing the quality assessment was the methodological disparity in the existing literature and study types.

Titles and abstracts were independently assessed by all authors. The inclusion of study in the review was based on full text assessment. Dissent among researchers concerning the worth of studies was resolved through discussion and mutual consent. The information extracted from these studies was discussed in various headings and subheadings.

Table I: Several species of coronaviruses and its emergence around the globe.

\begin{tabular}{|c|c|c|c|c|c|c|}
\hline Name of $\mathrm{CoV}$ & Genus & $\begin{array}{l}\text { Year of } \\
\text { outbreak }\end{array}$ & $\begin{array}{l}\text { Place of } \\
\text { outbreak }\end{array}$ & $\begin{array}{l}\text { Distribution of } \\
\text { virus } \\
\text { (Countries/spread/ } \\
\text { deaths) }\end{array}$ & $\begin{array}{l}\text { Incubation } \\
\text { period }\end{array}$ & Reference \\
\hline $\begin{array}{l}\text { Human CoV- } \\
229 \mathrm{E}\end{array}$ & Alpha & 1966 & $\begin{array}{l}\text { United } \\
\text { State of } \\
\text { America }\end{array}$ & Globally & 2-5 days & 65,66 \\
\hline $\begin{array}{l}\text { Human CoV- } \\
\text { NL63 }\end{array}$ & Alpha & 2004 & Netherland & Globally & 2-4 days & 65,67 \\
\hline $\begin{array}{l}\text { Human CoV- } \\
\text { HKU1 }\end{array}$ & Beta & 2005 & Hong Kong & Globally & 2-4 days & 65,68 \\
\hline $\begin{array}{l}\text { Human CoV- } \\
\text { OC43 }\end{array}$ & Beta & 1967 & $\begin{array}{l}\text { United } \\
\text { State of } \\
\text { America }\end{array}$ & Globally & 2-5 days & 65,69 \\
\hline SARS-CoV & Beta & $2002-2003$ & China & $\begin{array}{l}\text { Globally } \\
(26 / 8000 / 7740)\end{array}$ & 2-11 days & 65,70 \\
\hline MERS-CoV & Beta & 2012 & $\begin{array}{l}\text { Saudi } \\
\text { Arabia }\end{array}$ & $\begin{array}{l}\text { Globally } \\
(27 / 2494 / 858)\end{array}$ & 2-13 days & 65,71 \\
\hline SARS-CoV-2 & Beta & 2019 & China & $\begin{array}{l}\text { Globally } \\
(204 * / 634 \\
835 / 29957)\end{array}$ & 2-14 days & $33,72-74$ \\
\hline
\end{tabular}

\section{An overview of COVID-19 emergence and spread:}

A cluster of pneumonia patients with unknown etiology was observed on December 2019, in Wuhan (Hubei province), China. Initially, the disease was thought to be originated from the wild animals in wet market (known as Huanan Seafood wholesale Market), as most of the patients who experienced symptoms had history of visiting the market. Several hypotheses claimed that the virus is mutated and transferred from animals to humans, resulting in the first cluster. The virus was rapidly transmitted to family members and health professionals, indicating the contagious nature of the disease. Early evidences suggested that virus can transfer through close contact via air droplets and fomite. ${ }^{4-6}$ Initially, the morbidity of COVID-19 remained relatively low but the dramatic increase in confirmed cases was observed in the mid of January, with disease spillover to the adjacent regions. The virus spilled to the other parts of the world instantly amid enhanced community movements and travelling for Chinese New Year. ${ }^{7}$ The causative agent was identified with deep sequencing analysis in the samples extracted from lower respiratory tract and was designated as 2019-nCoV (2019 novel Coronavirus) by WHO. ${ }^{8,9}$ The scientific community around the globe responded quickly and recognized genomic sequence of the virus. ${ }^{10,}{ }^{11}$ Figure (2) describes the timeline of COVID-19 from its emergence to pandemic status.

\section{Global spread - response and actions:}

The outbreak was declared a Public Health Emergency of International Concern (PHEIC) by the WHO on January 30, 2020 following its spread to nineteen countries including mainland of China. The Coronavirus Study Group of the International Committee on Taxonomy of Viruses proposed the virus name as 'Severe Acute Respiratory Syndrome Coronavirus 2' (SARS $\mathrm{CoV}$-2) following its gene sequencing. ${ }^{14}$ The name of disease as 
COVID-19 (Coronavirus Disease 2019) was suggested by WHO on February $11,2020 .{ }^{15}$ Keeping in view the spread of disease to more than 100 countries, WHO declared pandemic on March 11, $2020 .{ }^{16}$ Despite vigorous manoeuvres to contain the virus, the disease transmitted to all major regions of WHO at the end of April.

Table II: Severity criteria of confirmed COVID-19 pneumonia. ${ }^{15}$

\begin{tabular}{|l|l|}
\hline Types & Findings \\
\hline \multirow{3}{*}{ Mild } & $\begin{array}{l}\text { Mild clinical symptoms [fever }<38^{\circ} \mathrm{C} \text { (quelled without } \\
\text { treatment), with or without cough, no dyspnoea, no gasping, no } \\
\text { chronic disease] No imaging findings of pneumonia }\end{array}$ \\
\hline Moderate & Respiratory symptoms, Fever, imaging findings of pneumonia \\
\hline \multirow{5}{*}{ Severe } & $\begin{array}{l}\text { Meet any of the followings: } \\
\text { Respiratory distress, respiratory rate } \geq 30 \text { times/min } \\
\text { Oxygen saturation (SpO2) }<93 \% \text { at rest } \\
\text { Partial pressure of oxygen (PaO2)/ fraction of inspired oxygen } \\
\text { (FiO2) } \leq 300 \text { mmHg. } \\
\text { Patients showing a rapid progression ( }>50 \% \text { ) on CT imaging } \\
\text { within 24-48 hours should be managed as severe. }\end{array}$ \\
\hline Critical & $\begin{array}{l}\text { Meet any of the followings: } \\
\text { Respiratory failure, need mechanical assistance } \\
\text { Shock } \\
\text { "Extra pulmonary" organ failure, intensive care unit is needed }\end{array}$ \\
\hline
\end{tabular}

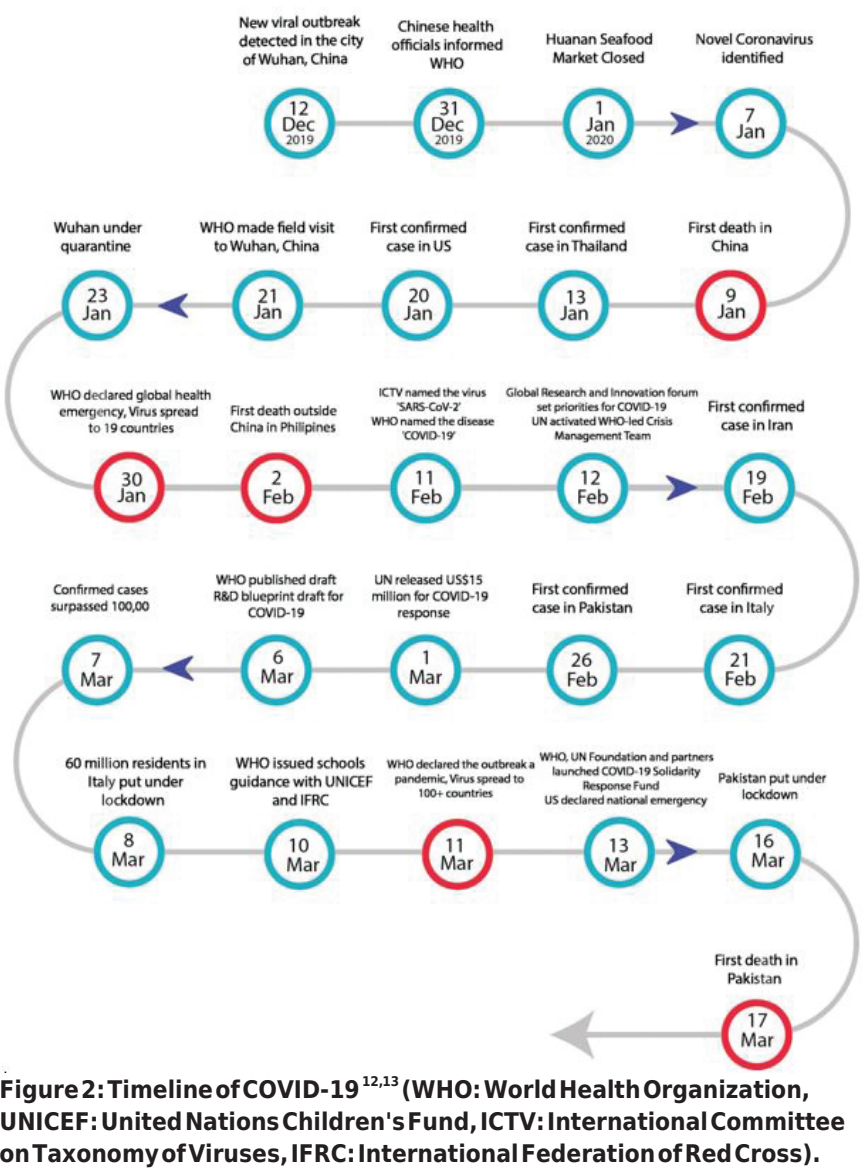

Virus structure and genome:

Sequencing of genome and phylogenetic analysis of virus demonstrated that this virus along with other viruses such as SARS-CoV and certain bat coronaviruses belong to the same subgenus called beta coronavirus and share same ancestor (Figure 3). The SARS-COV-2 showed genetic variability with $70 \%$ similarity with the genome of SARS-CoV in its genome. ${ }^{17,18}$ The MERS-CoV which is another beta coronavirus but relatively more distant in relation. ${ }^{19}$ Initial analysis revealed that sequence of RNA in SARS-COV-2 is closely related to those found in bats. These findings hypothesized bats as potential source of virus spread resulting in outbreak. However, it is not clear whether the transmission of SARS-CoV-2 humans is linked to other sources. ${ }^{20}$

The genomic structure in coronavirus has organization in a +ssRNA having approximate length of $30 \mathrm{~kb}$. It has a $5^{\prime}$-cap structure and 3'-poly-A tail. The viral RNA in the host synthesizes 1a/lab (ppala/pplab) polyprotein (Figure 4). Transcription occurs by RTC (Replication-Transcription Complex) in a double-membrane vesicle and through sgRNA (sub-genomic RNA) synthesis. Termination of transcription occurs at transcription regulatory sequences that are present between ORFs (open reading frames) which serve as templates to produce sub-genomic mRNAs. In a coronavirus genome, there can be at least 6 ORFs. Of these, a frame shift between the ORFla and ORF $1 b$ guides synthesis of the polypeptides ppla and pplab which are then processed by the 3CLpro (Chymotrypsin-like protease) or the Mpro (Main protease) and up to two papain-like proteases for production of sixteen nsps (non-structural proteins). Other open reading frames encode for the accessory protein chains and structural proteins such as nucleocapsid, membrane, spike and envelope proteins. Varying coronaviruses have special accessory and structural proteins translated by specific sgRNAs. Spike glycoproteins of coronaviruses have two subunits (S1 and S2) which are composed of homotrimers of $S$ proteins. They help the virus in binding to the host receptors which are believed to be membrane bound angiotensin-converting enzyme 2 (ACE2) in the case of SARS-CoV-2. ${ }^{21,22}$

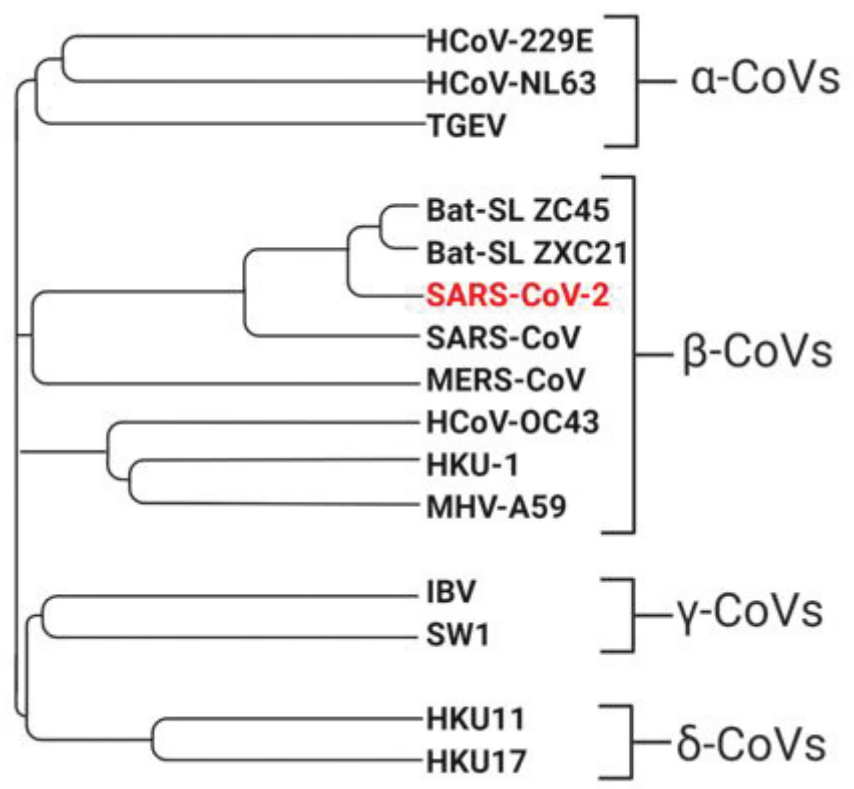

Figure 3: Phylogenetic tree of SARS-CoV-2. 


\section{Pathogenesis:}

The animal reservoir of SARS-CoV-2 is not known yet. However, the genomic characterisation shows similarity of $79 \%$ and $50 \%$ with SARS-COV and MERS-COV, respectively. ${ }^{23,24}$ Regardless of the variations, recent evidences underscore that SARS-CoV-2 uses ACE2 receptor to gain access to the target host cells, same target used by SARS-CoV during pathogenesis. ${ }^{24,25}$ However, the binding affinity of new virus is higher than other Coronaviruses. ${ }^{26}$ ACE2 is a dipeptidylcarboxypeptidase that removes carboxy-terminal hydrophobic or basic amino acids. ACE2 cleaves Angiotensin I, generating Angiotensin 1-9, and Angiotensin II to generate Angiotensin 1-7, which has vasodilating effect opposed to Angiotensin II generated by angiotensin converting enzy$\mathrm{me}^{27,28}$

A study reported high expression of ACE2 in the oral mucosa, which facilitates the entry of virus in the host. ${ }^{29}$ ACE2 is usually expressed on type 1 and 2 alveolar epithelial cells in the lower lungs. After its infection, SARS-CoV-2 starts to enter alveolar cells through the binding of the spike glycoprotein to ACE2 on the alveolar surface. This binding causes the clathrin-dependentendocytosis of the whole SARS-CoV-2 and ACE2 complex. pH-dependent endosomal cysteine protease cathepsins and low $\mathrm{pH}$ facilitates endosomal cell entry of SARS-CoV-2. After entrance into the cell, SARS-COV-2 exploits the transcriptional machinery of the host alveolarcells for replication, spreading to the entire lung. ${ }^{30}$ When most of the ciliated cells of alveoli are infected, the normal activities of these cells (such as airways clearance) are stopped and progressive accumulation of fluids and debris occurs in the lungs resulting in acute respiratory distress syndrome (ARDS). ${ }^{31}$

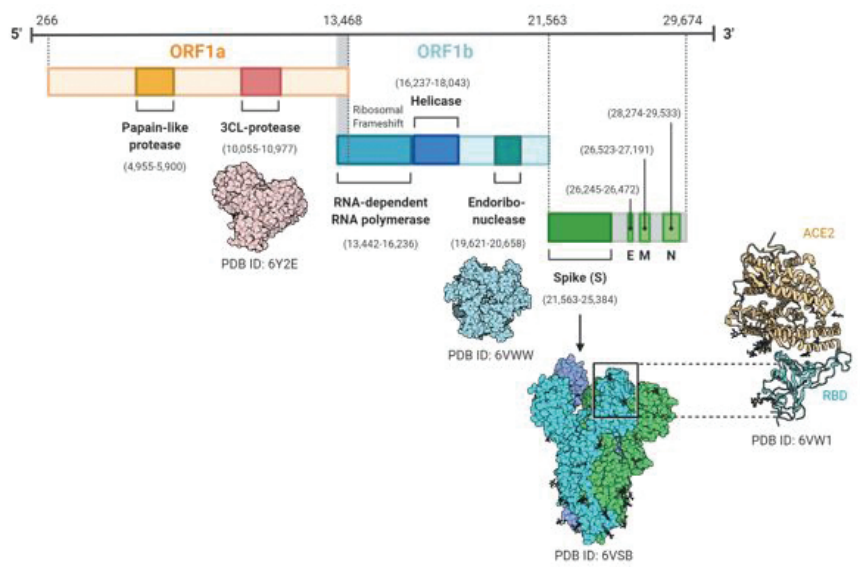

Figure 4: The genomic structure of SARS-CoV-2 by Abrar Ahmad; Made with Biorender.com (S, E, M, and $\mathbf{N}$ indicate the four structural proteins spike, envelope, membrane, and nucleocapsid).

Recent investigations show that viral infection of SARS-CoV-2 can trigger an excessive immune response known as cytokine storm. This immune reaction results in extensive damage to tissues. The main protagonist of this response is interleukin 6 (IL-6), which acts on many cells and tissues and is produced by the activated leukocytes. Cytokine storm causes acute systemic inflammation resulting in fever and multiple organ dysfunction. ${ }^{22}$ Figure (5) demonstrates the possible viral replication mechanism in the host cells.

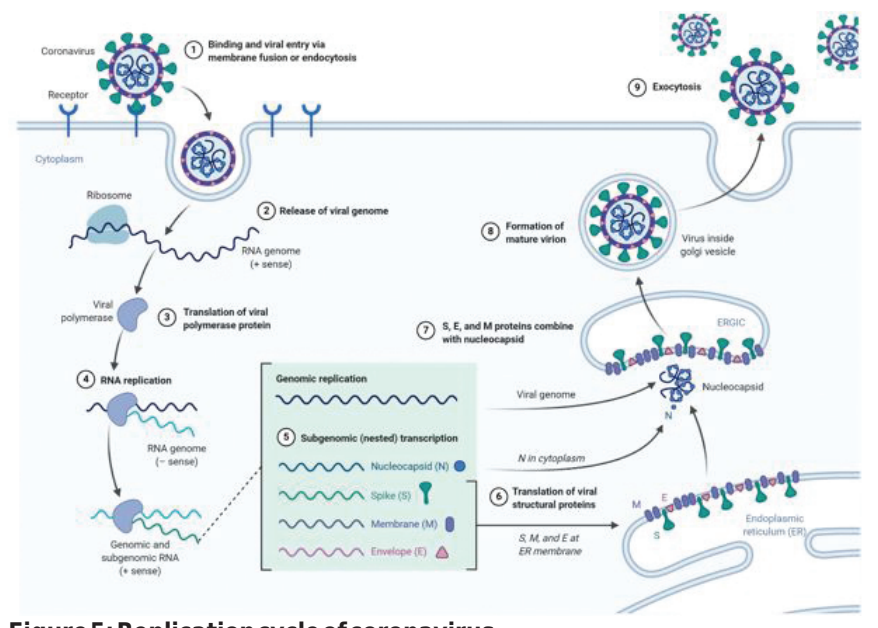

Figure 5: Replication cycle of coronavirus.

\section{Clinical manifestations:}

COVID-19, like other beta coronaviruses, varies in clinical manifestations from mild respiratory anomalies to septic shock. Similar to the SARS and MERS, initial symptoms revolve around dry cough, fever and shortness of breath. ${ }^{32}$ Though diarrhoea has been reported in $20 \%$ to $25 \%$ of MERS and SARS cases but its prevalence is quite low in COVID-19. However, one study also reported nausea, vomiting, chest pain and confusion along with primary symptoms. ${ }^{33}$ Chest CT and X-ray imaging of COVID-19 cases revealed unilateral or bilateral involvement compatible with viral pneumonia, and bilateral multiple lobular and sub segmental consolidation regions were seen in patients admitted to intensive care unit (ICU). ${ }^{10} \mathrm{~A}$ study on 41 COVID-19 cases ${ }^{9}$ reported dry cough, fever, fatigue and myalgia in most of the patients while headache, expectoration, diarrhoea and haemoptysis were infrequent in these cases. The study reported that $32 \%$ positive cases had comorbid conditions such as hypertension, cardiovascular disease and diabetes mellitus. Patients also developed shortness of breath with abnormal chest CT as well as pneumonia. Subgroup analysis revealed that patients with underlying comorbidities portend severe clinical manifestations as compared to those without any comorbid condition. Available evidence suggest substantial association of disease severity with mortality rate. ${ }^{34}$ The severity criteria of COVID-19 are described in Table(II). ${ }^{15}$

\section{Laboratory profile:}

Patients with COVID-19 present with elevated pro-inflammatory cytokines and abnormal respiratory findings. A case study demonstrated that patient with fever history of 5 days presented with coarse breathing sounds of both lungs, cough and hyperthermia $\left(39^{\circ} \mathrm{C}\right) .^{35}$ Laboratory studies showed leukopenia with counts of $2.91 \times 10^{\wedge} 9$ cells/L, $70 \%$ of which were neutrophils, and increased value of $\mathrm{C}$-reactive protein (16.16 mg/L; normal range, $0-10 \mathrm{mg} / \mathrm{L}$ ) in blood. Observations also included elevated erythrocyte sedimentation rate (29 $\mathrm{mm} / \mathrm{h}$; normal range, $<20 \mathrm{~mm} / \mathrm{h})$ and D-dimer $(580 \mathrm{ng} / \mathrm{mL}$; normal range, $500 \mathrm{ng} / \mathrm{mL}$ ). ${ }^{13}$ Clinical manifestations of severe COVID-19 include severe pneumonia, RNAaemia with ground-- 
glass opacities in imaging and acute cardiac injury. Moreover, patients showed significantly high levels of chemokines and cytokines in the blood. These include IL1- $\beta$, IL1RA, IL7, IL8, IL9, IL10, basic FGF2, GCSF, GMCSF, IFN $\gamma$, IP10, MCP1, MIP1 $\alpha$, MIP1 $\beta$, PDGFB, TNF $\alpha$, and VEGFA. Severe patients admitted to intensive care unit (ICU) showed increased levels of pro-inflammatory cytokines including IL2, IL7, IL10, GCSF, IP10, MCP1, MIP $1 \alpha$, and TNF $\alpha$. Studies have elaborated that these cytokines are associated with the disease severity. ${ }^{23}$

Table III: Comparison of influenza, common cold, MERS, SARS, and COVID-19.

\begin{tabular}{|c|c|c|c|c|c|}
\hline Diseases & $\begin{array}{l}\text { Incubation } \\
\text { Period }\end{array}$ & $\begin{array}{l}\text { Respiratory } \\
\text { symptoms }\end{array}$ & $\begin{array}{l}\text { Constitutional } \\
\text { symptoms }\end{array}$ & $\begin{array}{l}\text { CT imaging } \\
\text { findings }\end{array}$ & Reference \\
\hline $\begin{array}{l}\text { Common } \\
\text { cold }\end{array}$ & 1-3 Days & $\begin{array}{l}\text { Stuffy nose, } \\
\text { runny noses, } \\
\text { sneeze }\end{array}$ & $\begin{array}{l}\text { No obvious } \\
\text { discomfort }\end{array}$ & Usually normal & 15 \\
\hline Influenza & 1-4 Days & $\begin{array}{l}\text { Stuffy nose, } \\
\text { runny noses, } \\
\text { sore throat and } \\
\text { dry cough }\end{array}$ & $\begin{array}{l}\text { High fever, } \\
\text { muscle ache, } \\
\text { malaise }\end{array}$ & $\begin{array}{l}\text { Small patch GGO } \\
\text { and consolidation } \\
\text { with subpleural } \\
\text { and/or peri- } \\
\text { bronchial } \\
\text { distribution }\end{array}$ & 75,76 \\
\hline SARS & 2-11 Days & $\begin{array}{l}\text { Cough, } \\
\text { dyspnoea }\end{array}$ & $\begin{array}{l}\text { Fever, chill, } \\
\text { malaise, } \\
\text { headache, } \\
\text { diarrhoea }\end{array}$ & $\begin{array}{l}\text { Subpleural GGO } \\
\text { and consolidation } \\
\text { prominent lower } \\
\text { lobe involved, } \\
\text { interlobular septal } \\
\text { and intralobular } \\
\text { septal thickening }\end{array}$ & $77-80$ \\
\hline MERS & 2-13 Days & $\begin{array}{l}\text { Sore throat, } \\
\text { dry cough, } \\
\text { dyspnoea }\end{array}$ & Fever, chill, rigor & $\begin{array}{l}\text { Bilateral, basilar } \\
\text { and subpleural } \\
\text { airspace, } \\
\text { extensive GGO and } \\
\text { occasional septal } \\
\text { thickening and } \\
\text { pleural effusions }\end{array}$ & $15,65,80$ \\
\hline COVID-19 & 2-14Days & $\begin{array}{l}\text { Cough or not, } \\
\text { sore throat, } \\
\text { Breathless, } \\
\text { respiratory } \\
\text { failure }\end{array}$ & $\begin{array}{l}\text { Fever, Fever, } \\
\text { muscle ache, } \\
\text { confusion, } \\
\text { headache }\end{array}$ & $\begin{array}{l}\text { Multifocal patchy } \\
\text { GGOs with } \\
\text { subpleural } \\
\text { distribution. } \\
\text { Diffused } \\
\text { heterogeneous } \\
\text { consolidation with } \\
\text { GGO }\end{array}$ & $4,33,81$ \\
\hline
\end{tabular}

\section{High-risk groups:}

The data on risk factors of virus contraction and disease severity is limited. Currently available evidences stratify various groups of patients with high propensity of disease contraction and severity. These include advanced age ( $\geq 65$ years), obesity, population living in long-term care facilities (e.g. nursing homes), patients with chronic respiratory diseases such as asthma, cardiac diseases, immunocompromised population including those with underlying malignancies, and patients with comorbid conditions such as Diabetes mellitus, hypertension, liverdisease or renal failure. ${ }^{36,37}$

\section{Diagnosis and differential diagnosis:}

Like SARS and MERS, the diagnosis of COVID-19 is based on contact and travel history along with laboratory testing. Diagnostic investigations revolve around viral culture, serology and molecular methods. Molecular methods include real-time PCR which examines viral RNA in sputum, nasopharyngeal aspirate, oropharyngeal swabs, bronchoalveolar lavage or deep tracheal aspirate. Samples from the lower respiratory tract contain higher viral load and genome fraction relative to the samples from the upper respiratory tract. This method aids in quickevaluation of results, quantifies the viral load and illustrates genome fraction. ${ }^{19}$ Compared to the molecular method, sensitivity of antibody detection is lower. Moreover, antibody detection is usually used retrospectively during the diagnosis. Viral culture is more time-taking process and only useful in the initial stages of outbreaks when other diagnostic methods are not readily available. Culture methods are also very useful for in-vitro and in-vivo trials of antiviral drugs orvaccines. ${ }^{17}$

Table IV: Potential vaccines and drugs for COVID-19..$^{59,82,83}$

\begin{tabular}{|c|c|}
\hline $\begin{array}{l}\text { Vaccines and Drugs } \\
\text { (Company Name) }\end{array}$ & Current Status of development \\
\hline \multicolumn{2}{|c|}{ Vaccines and their status of Development } \\
\hline $\begin{array}{l}\text { INO-4800 } \\
\text { (Inovio Pharmaceuticals) }\end{array}$ & $\begin{array}{l}\text { Phase } 1 \text { human clinical trials are expected to begin in April } \\
2020\end{array}$ \\
\hline $\begin{array}{l}\text { mRNA-1273 } \\
\text { (Moderna Inc.) }\end{array}$ & $\begin{array}{l}\text { Phase } 1 \text { human clinical trials has been initiated in } 45 \\
\text { healthy volunteers }\end{array}$ \\
\hline $\begin{array}{l}\text { mRNA vaccine } \\
\text { (CureVac) }\end{array}$ & Vaccine under development \\
\hline $\begin{array}{l}\text { mRNA vaccine BNT162 } \\
\text { (BioNTech and Pfizer) }\end{array}$ & mRNA-based vaccine candidate initiated. \\
\hline $\begin{array}{l}\text { COVID-19 S-Trimer } \\
\text { (GlaxoSmithKline and } \\
\text { Clover Biopharmaceuticals) }\end{array}$ & $\begin{array}{l}\text { Preclinical development is started using GSK's adjuvants } \\
\text { (compounds that enhance vaccine efficacy) and Clover's } \\
\text { proprietary proteins, which stimulate an immune } \\
\text { response. }\end{array}$ \\
\hline $\begin{array}{l}\text { SARS-CoV-2 vaccine } \\
\text { (Johnson \& Johnson) }\end{array}$ & $\begin{array}{l}\text { Partnering with the Biomedical advanced Research and } \\
\text { Development Authority to develop vaccine candidate. }\end{array}$ \\
\hline $\begin{array}{l}\text { Live-attenuated vaccine } \\
\text { (Codagenix) }\end{array}$ & $\begin{array}{l}\text { Codagenix is collaborating with the Serum Institute of } \\
\text { India to co-develop a live-attenuated vaccine. }\end{array}$ \\
\hline $\begin{array}{l}\text { PCR-based DNA vaccine } \\
\text { (Applied DNA Sciences and } \\
\text { Takis Biotech) }\end{array}$ & $\begin{array}{l}\text { Designed four COVID-19 vaccine candidates using PCR- } \\
\text { based DNA manufacturing systems for preclinical testing } \\
\text { in animals. }\end{array}$ \\
\hline $\begin{array}{l}\text { Intranasal COVID-19 } \\
\text { vaccine (Altimmune, Inc) }\end{array}$ & $\begin{array}{l}\text { Design and synthesis has been completed and soon start } \\
\text { animal testing. }\end{array}$ \\
\hline $\begin{array}{l}\text { HaloVax } \\
\text { (Hoth Therapeutics; Voltron } \\
\text { Therapeutics) }\end{array}$ & $\begin{array}{l}\text { Collaborate with the Vaccine and Immunotherapy Center } \\
\text { of the Massachusetts General Hospital for rapid } \\
\text { development of vaccine. }\end{array}$ \\
\hline $\begin{array}{l}\text { PittCoVax } \\
\text { (University of Pittsburgh } \\
\text { School of Medicine) }\end{array}$ & $\begin{array}{l}\text { Vaccine candidate using microneedle transdermal for } \\
\text { COVID-19. Testing in mice produced antibodies over a 2- } \\
\text { week period. }\end{array}$ \\
\hline $\begin{array}{l}\text { Infectious Bronchitis Virus } \\
\text { vaccine (MIGAL) }\end{array}$ & Pre-clinical trials \\
\hline APN01 (APEIRON Biologics) & Phase I \\
\hline $\begin{array}{l}\text { TNX-1800 (Tonix } \\
\text { Pharmaceuticals) }\end{array}$ & Initial evaluation \\
\hline $\begin{array}{l}\text { Brilacidin (Innovation } \\
\text { Pharmaceuticals) }\end{array}$ & Initial evaluation \\
\hline $\begin{array}{l}\text { S-Trimer vaccine (Clover } \\
\text { Biopharmaceuticals) }\end{array}$ & Pre-clinical trials \\
\hline TBC (Vaxart) & Pre-clinical trials \\
\hline Leronlimab (CytoDyn) & Phase II for HIV and fast tracked for COVID-19 \\
\hline $\begin{array}{l}\text { Linear DNA Vaccine } \\
\text { (Applied DNA Sciences and } \\
\text { Takis Biotech) }\end{array}$ & Pre-clinical trials \\
\hline \multicolumn{2}{|c|}{ Drugs and their status of Development } \\
\hline Chloroquine & In vitro approve \\
\hline Remdesivir & Phase III testing start \\
\hline hydroxychloroquine & Phase III testing start \\
\hline $\begin{array}{l}\text { Favipiravir (viral RNA } \\
\text { polymerase inhibitor). }\end{array}$ & Investigation stage \\
\hline $\begin{array}{l}\text { Sarilumab (Interleukin-6 } \\
\text { inhibitors) }\end{array}$ & initiation of a phase II/III trial \\
\hline $\begin{array}{l}\text { Azvudine (nucleoside } \\
\text { reverse transcriptase } \\
\text { inhibitor) }\end{array}$ & Investigation stage \\
\hline Plitidepsin (targets EF1A) & Investigation stage \\
\hline $\begin{array}{l}\text { Danoprevir (NS3/4A HCV } \\
\text { protease inhibitor) }\end{array}$ & Investigation stage \\
\hline $\begin{array}{l}\text { Tradipitant (neurokinin-1 } \\
\text { (NK-1) receptor antagonist) }\end{array}$ & Phase III \\
\hline $\begin{array}{l}\text { rintatolimod (toll-like } \\
\text { receptor } 3 \text { [TLR-3] agonist) }\end{array}$ & Potential treatment for COVID-19 \\
\hline Inhaled nitric oxide ${ }^{72}$ & $\begin{array}{l}\text { Phase II study of iNO is underway in patients with } \\
\text { COVID-19 with the goal of preventing disease progression }\end{array}$ \\
\hline $\begin{array}{l}\text { Ifenprodil ( } \mathrm{N} \text {-methyl-d- } \\
\text { aspartate receptor } \\
\text { glutamate receptor } \\
\text { antagonist) }\end{array}$ & Start clinical trials for COVID-19 and acute lung injury \\
\hline $\begin{array}{l}\text { Anti-SARS-CoV-2 polyclonal } \\
\text { hyperimmune globulin }\end{array}$ & Under development to treat high-risk patients \\
\hline
\end{tabular}

It is pertinent to mention that COVID-19 shares most of the clinical manifestations of common cold, influenza, MERS and SARS. In this context, differential diagnosis is of utmost importance, 
particularly during the current pandemic. Table(III) demonstrates the differentiating characteristics between these five closely related viral infections.

\section{Complications:}

Complications of COVID-19 include secondary infections, acute heart damage, pneumothorax and acute respiratory distress syndrome. Complications are more profound among patients with pre-existing comorbid illnesses. ${ }^{34}$ However, there is a dearth of investigations evaluating the long-term intricacies of the COVID-19.

\section{Routes of transmission:}

The transmission of COVID-19 shares similar pathways as for other respiratory viruses. It can transmit through air droplets from cough and sneezing. The initial cases with history of visiting wet market suggest animal to human transmission and subsequent spread of the disease confirms human to human transmission. Both symptomatic and asymptomatic patients have been observed as potential sources of virus. ${ }^{22}$ Analysis of stool of COVID-19 patients revealed the presence of SARS-CoV-2 nucleic acid. Moreover, various other studies have also demonstrated that the transmission can also occur through faecal-oral route. ${ }^{38-41}$

Viruses also spread through inanimate objects, also referred as fomites, which include door handles, clothes and respirators. ${ }^{42}$ Fomite transmission of disease is also observed during the current pandemic. ${ }^{6}$ In line to these studies, frequent hand washing (at least 20 seconds), sanitization and precautionary measures were suggested for the general public.

A study conducted by Chen et al. among pregnant women having confirmed diagnosis of COVID-19. The vertical transmission by intrauterine route was assessed by testing neonates' cord blood, amniotic fluid and throat swab samples. However, the results were negative and there is no evidence of vertical and intrauterine transmission of SARS-CoV-2. ${ }^{43}$ Furthermore, the exposure levels of faecal contamination, aerosol transmission, and close contact with the mother could boost neonatal COVID-19 infected pneumonia in neonates. So far, there are no reports of COVID-19 through blood contact. ${ }^{44}$ Recent studies also suggest the risk of transmission through aerosol. ${ }^{45}$ Aerosol transmission is well documented for influenza and it is suggested that improvement in design of ventilation and avoidance aerosol generation can reduce the transmission. ${ }^{46}$ However, there is no evidence for aerosol-based transmission but the odds of such transmission is higher among healthcare professionals. ${ }^{41}$

\section{Treatments:}

Currently, there is no specific treatment or vaccines available for COVID-19. Certain drugs are being tested in-vitro and some drugs are in variable stages of clinical trials on MERS-COV and SARS-CoV. Studies which evaluated interferon types (I and II) for their antiviral activity show that Interferon-beta (IFNb) had the most potent activity against MERS-CoV, reducing replica- tion in-vitro. ${ }^{43}$ Case reports of MERS-CoV patients from South Korea indicated successful clearance of virus using combination of LPV/RTV (Lopinavir/Ritonavir), ribavirin and pegylated interferon. ${ }^{47}$ In 2016, randomized control trials consisting of 76 patients were initiated to determine the effectiveness of LPV/RTV - IFNb in improving clinical outcomes of MERS-COV infection. ${ }^{48}$ Remdesivir, another drug when used in the first patient in United States of America, seemed to be successful, however, further trials are needed to affirm these findings. ${ }^{17}$

In in-vitrostudies, Remdesivir has shown effectiveness in inhibition of RNA transcription in the early stage in SARS-CoV-2..$^{49,50}$ Some studies reported strong antiviral activity of remdesivir against SARS-COV, MERS-COV and other coronaviruses in the culture of epithelial cells. ${ }^{51,52}$ Currently, various drugs are repurposed against COVID-19. Keeping in view the established safety profile, FDA allowed healthcare professionals to test these medications among COVID-19 patients. These medicines include chloroquine, hydroxychloroquine, azithromycin, ivermectin and favipiravir. Moreover, these drugs are also in various stages of clinical trials in order to ascertain their efficacy and safety for COVID-19. ${ }^{53-56}$

Ivermectin is FDA approved anti-parasitic drug and has previously shown in-vitro effectiveness against viruses including $H I V$, dengue and influenza. Recent investigation showed invitro effectiveness of ivermectin against SARS-CoV-2 in cell cultures. These findings underscore that ivermectin can reduce the viral count up to 5000 folds within 48 hours following the single treatment. ${ }^{57}$ Despite the established safety profile of ivermectin, more in-vivo trials are necessary to establish its efficacy in COVID-19.

Convalescent plasma transfusion is another approach for the treatment of COVID-19 and involves the administration of plasma from the recovered patients. This approach has been widely tested during Ebola and MERS outbreaks. A recent study showed that plasma administration in five critically ill patients demonstrated substantial clinical improvements followed the transfusion ${ }^{58}$ However, there is dire need to test this approach in randomised controlled trials. It must be noted that the practicality of this method is questionable when considering the logistical and funding needs. This method requires designation of staff and department, collection, freezing, storage and transportation of plasma. Table (IV) elaborates potential candidates for COVID-19 treatment and their current status of development in the clinical management of patients.

\section{Vaccine development:}

The vaccine for COVID-19 is in developing stages by various pharmaceutical industriesand researchinstitutes. INOVIO Pharmaceuticals announced the first animal testing and is expected to enter the clinical trials in April, 2020. Australian researchers from University of Queensland have also announced animal testing following the satisfactory in-vitro investigations. The National Institute for Allergy and Infectious Diseases (NIAID) in USA announced that phase 1 trial has been started forimmuniza- 
tion of COVID-19. ${ }^{22,59}$ It will likely take more than a year for the vaccines to be approved and publicly available. Table (IV) elaborates potential candidates for COVID-19 vaccine and their current status of development.

\section{Prevention:}

China was the first country initiating the vigorous preventive measures for COVID-19. The effectiveness of these measures taken by the Chinese health authorities is attributed to their past experience with SARS outbreak in 2003-2004. These measures included restricted public transport, travels and migration. Moreover, they informed public to use effective personal protection such as masks during the outbreak. The disease spillover to healthcare professionals and hospital staff was also reported during SARS outbreak. The primary precautionary measure for health professionals was the use of personal protective equipment (PPE) including gloves, N95 respirators and eye shields. ${ }^{33}$

Several measures should be taken to contain the infection including timely publication of information related to the epidemics, early diagnosis, reporting, isolation and provision of supportive treatment. However, prevention of public panic towards outbreak is of paramount importance. Centre for Disease Control and Prevention (CDC) recommends measures similar to those for common cold and flu, such as frequent hand wash with soap for at least 20 seconds or hand sanitization, use of disinfectants and avoiding close contact with known or suspected cases. Precautionary steps are also necessary in healthcare system such as the timely and sufficient supply of medicines, PPE and other hospital supplies necessary for virus containment and care of patients. ${ }^{17}$

Currently, prevention is the primary strategy to reduce the spread of COVID-19 among people. Patients' isolation and infection control measures have been adopted by the various countries experiencing the outbreak. Moreover, suitable protective methods must also be utilized during the diagnosis and clinical care of patients. Droplet, airborne and contact precautions are of paramount importance while collecting samples and sputum induction.

General recommendations issued by the WHO, which were later endorsed by various other organisations, are described below:

Avoid contact with respiratory infection patients.

Frequenthandwash (atleast 20 seconds).

Avoid contact with wild animals.

Cover coughs with disposable tissues and immediate handwashing following cough.

Hygienic measures should be taken for the control of infection and prevention.

Immunocompromised patients should not attend any gatherings. Use sanitiser where handwash with soap is not possible.

Paramedical staff should wear face masks, gowns, gloves and eye protection to prevent pathogens' transmission.

\section{Role of pharmacist:}

Pharmacists are most accessible healthcare professional around the globe. Community pharmacists are vital healthcare providers during the outbreak; they remain on the frontline of public health by serving as direct points of access for their patients. Moreover, hospital pharmacists are playing pivotal role in provision of patient care and support. ${ }^{60}$ Pharmacists are responsible for provision of standardised, ethical and optimal care to the public. Moreover, public outreach to the pharmacists is easy and does not bear any cost, particularly during the near enough global lockdown. However, prevention and control practices must be implemented in the pharmacies before educating the public. ${ }^{61}$ International Pharmaceutical Federation (FIP) stressed the active involvement of hospital and community pharmacists to contain the SARS-CoV-2. During the currentlockdown which has been imposed by numerous countries, there seems to be an even greater dependence on pharmacists as the first point of contact to fulfil the public's healthcare needs. ${ }^{62}$ The primary responsibilities of pharmacists may include but not limited to maintenance of drug inventory at appropriate levels, promotion of hand and personal hygiene, in-hospital infection control measures, provision of care and support to the patients, education of paramedics and nurses and arrangements to counter drug shortages. Community pharmacist can play a crucial role in early detection and prevention of new cases by reporting suspects to the healthcare authorities. Since research on the management of COVID-19 is quite dynamic amid rapid publications, pharmacists can serve as potential source of information on treatment and care of COVID-19 patients. As opportunistic infections can occur during the course of COVID-19, hospital pharmacists should have updated information on identifying and managing such infections. ${ }^{63,64}$ Moreover, being an expert of drugs, pharmacists can actively involve in drug and vaccine discovery. The clinical care of COVID-19 patients is of utmost priority for healthcare providers. Pharmacists may assist in developing and implementing treatment guidelines or algorithm in accordance with the updated protocols. ${ }^{62}$ In addition, pharmacists working in drug regulatory authorities should ensure the uncut supply of medications, particularly those that are being used in the care of COVID-19 patients.

\section{Preparedness for future events:}

World has witnessed three attacks of coronaviruses including SARS-COV (which emerged in 32 countries) MERS-CoV in 2013 and COVID-19 in 2019. These outbreaks posed serious challenges to healthcare system to contain the virus and it might be attributed to the novel nature of these viruses during the epidemics. COVID-19 has caused quadruple damage to overwhelmed healthcare system in the developing countries. However, many developed nations with sophisticated health system responded well during the current pandemic. The unavailability of medicines and vaccines pose serious risks of future events which might be new emergence or re-emergence. The global collaboration and effort of the scientific community in this time is unprecedented but further research is necessary to find ways to combat the growing encumbrance of infection. Considering the existing and previous outbreaks, similar future 
outbreaks are inevitable. However, health authorities around the globe can decrease the damage of similar future events by getting lessons from the current pandemic. Implementing effective precautionary measures, reinforcing and developing epidemiological forces or systems to detect potential pathogens at initial stages of zoonotic emergence after cross-species transmission and preventing the further transmission in population can go a long way to strengthen the infection control. Authorities should also implement strict rules banning wild-life trade and live animal wet markets where human-animal interaction increases the risk of cross-species transfer and zoonotic disease emergence. These sources of viruses must be under the control of health authorities in a similar way as for slaughterhouse around the world. Since researchers have gained much control on bacterial infections, future investigations must be tailored to the viral diseases as most of them lack specific treatments amid variations in viral structures.

Health authorities around the globe should focus their efforts on vertical programmes forthe control of zoonotic diseases, coordination and closer integration of health departments, collaboration with intergovernmental organisations such as the World Organization for Animal Health (OIE), implementation and monitoring of policies for effective surveillance, fostering of collaboration among infectious disease researchers, and informative campaigns that target the general public and healthcare professionals. Moreover, collaborative efforts among countries experiencing the COVID-19 outbreak will further strengthen the infection control efforts.

\section{CONFLICT OF INTEREST:}

All the authors declared no conflict of interest.

\section{AUTHORS' CONTRIBUTION:}

$A A, M H B, T H M$ : Conception or design of the work.

$\mathrm{SM}, \mathrm{MHB}, \mathrm{NHA}$ : Analysed or interpreted the data for the work. $A A, M H B, Y H K$ : Drafted the work.

THM, YHK, NHA: Revised the manuscript critically for important intellectual content.

SM, AA, MHB, YHK, NHA, THM: Provided approval for publication of the content.

\section{REFERENCES}

1. van der Hoek L, Pyrc K, Jebbink MF, Vermeulen-Oost W, Berkhout RJM, Wolthers KC, et al. Identification of a new human coronavirus. Nature Med 2004; 10(4):368-73.

2. Guy JS, Breslin JJ, Breuhaus B, Vivrette S, Smith LG. Characterization of a coronavirus isolated from a diarrheic foal. J Clin Microbiol 2000; 38(12):4523-26.

3. Cui J, Li F, Shi Z-L. Origin and evolution of pathogenic coronaviruses. Nat Rev Microbiol 2019; 17(3):181-92.

4. Chan JF-W, Yuan S, Kok K-H, To KK-W, Chu H, Yang J, et al. A familial cluster of pneumonia associated with the 2019 novel coronavirus indicating person-to-person transmission: a study of a family cluster. Lancet 2020; 395(10223):514-23.

5. Zhou P, Yang X-L, Wang X-G, Hu B, Zhang L, Zhang W, et al. A pneumonia outbreak associated with a new coronavirus of probable bat origin. Nature 2020; 1-4.
6. Galbadage T, Peterson BM, Gunasekera RS. Does COVID-19 Spread Through Droplets Alone? Front Public Health 2020; 8:1-4.

7. Mackenzie JS, Smith DW. COVID-19: a novel zoonotic disease caused by a coronavirus from China: what we know and what we don't. Microbiol Aust 2020; 41(1):45-50.

8. Song F, Shi N, Shan F, Zhang Z, Shen J, Lu H, et al. Emerging coronavirus 2019-nCoV pneumonia. Radiology 2020; 200274.

9. Huang C, Wang Y, Li X, Ren L, Zhao J, Hu Y, et al. Clinical features of patients infected with 2019 novel coronavirus in Wuhan, China. Lancet 2020; 395(10223):497-506.

10. Zhu N, Zhang D, Wang W, Li X, Yang B, Song J, et al. A novel coronavirus from patients with pneumonia in China, 2019. N Eng J Med 2020; 382:727-33.

11. Wu F, Zhao S, Yu B, Chen Y-M, Wang W, Song Z-G, et al. A new coronavirus associated with human respiratory disease in China. Nature 2020; 1-5.

12. Organization $\mathbf{W H}$. Rolling updates on coronavirus disease (COVID-19): WHO; March, 2020. [Available from: http:// www.who.int/emergencies/diseases/novel-coronavirus-2019/ events-as-they-happen.

13. Rothan HA, Byrareddy SN. The epidemiology and pathogenesis of coronavirus disease (COVID-19) outbreak. J Autoimmun 2020: 102433.

14. Mclntosh K, Hirsch MS, Bloom A. Coronavirus disease 2019 (COVID-19). UpToDate, retrieved from http://www. uptodatecom/contents/coronavirus-disease-2019-covid-19epidemiology-virology-clinical-features-diagnosis-andprevention (Accessed on March 27, 2020).

15. Zu ZY, Jiang MD, Xu PP, Chen W, Ni QQ, Lu GM, et al. Coronavirus disease 2019 (COVID-19): a perspective from China. Radiology 2020; 295(3):715-21.

16. Guo Y, Huang Y, Huang J, Jin Y, Jiang W, Liu P, et al. COVID-19 Pandemic: global epidemiological trends and China's subsequent preparedness and responses. Zhonghua Liu Xing Bing Xue Zaz Hi 2020; 41(5):643.

17. Sahin AR, Erdogan A, Agaoglu PM, Dineri Y, Cakirci AY, Senel ME, et al. 2019 Novel Coronavirus (COVID-19) Outbreak: A Review of the Current Literature. EJMO 2020; 4(1):1-7.

18. Gralinski LE, Menachery VD. Return of the Coronavirus: 2019-nCoV. Viruses 2020; 12(2):135.

19. Zhu N, Zhang D, Wang W, Li X, Yang B, Song J, et al. A novel coronavirus from patients with pneumonia in China, 2019. N England J Med 2020; 382:727-33.

20. Perlman S. Another decade, another coronavirus. Mass Medical Soc 2020; 760-62.

21. Song W, Gui M, Wang X, Xiang Y. Cryo-EM structure of the SARS coronavirus spike glycoprotein in complex with its host cell receptor ACE2. PLoS Pathogens 2018; 14(8):e1007236.

22. Cascella M, Rajnik M, Cuomo A, Dulebohn SC, Di Napoli R. Features, Evaluation and treatment coronavirus (COVID-19). StatPearls [Internet]: StatPearls Publishing; 2020.

23. Lu R, Zhao X, Li J, Niu P, Yang B, Wu H, et al. Genomic characterisation and epidemiology of 2019 novel coronavirus: implications for virus origins and receptor binding. Lancet 2020; 395(10224):565-74.

24. Hoffmann M, Kleine-Weber H, Schroeder S, Krüger N, Herrler $\mathrm{T}$, Erichsen S, et al. SARS-CoV-2 cell entry depends on ACE2 
and TMPRSS2 and is blocked by a clinically proven protease inhibitor. Cell 2020; 181(2):271-80.

25. Chen N, Zhou M, Dong X, Qu J, Gong F, Han Y, et al. Epidemiological and clinical characteristics of 99 cases of 2019 novel coronavirus pneumonia in Wuhan, China: a descriptive study. Lancet 2020; 395(10223):507-13.

26. Wrapp D, Wang N, Corbett KS, Goldsmith JA, Hsieh C-L, Abiona O, et al. Cryo-EM structure of the 2019-nCoV spike in the prefusion conformation. Science 2020; 367(6483): 1260-63.

27. Federation IP. COVID-19: Guidelines for pharmacists and the pharmacy workplace; 2020.

28. Ye M, Wysocki J, William J, Soler MJ, Cokic I, Batlle D. Glomerular localization and expression of angiotensinconverting enzyme 2 and angiotensin-converting enzyme: implications for albuminuria in diabetes. J Am Soc Nephrol 2006; 17(11):3067-75.

29. Xu H, Zhong L, Deng J, Peng J, Dan H, Zeng X, et al. High expression of ACE2 receptor of 2019-nCoV on the epithelial cells of oral mucosa. Int J Oral Sci 2020; 12(1):1-5.

30. Zumla A, Chan JF, Azhar El, Hui DS, Yuen K-Y. Coronaviruses-drug discovery and therapeutic options. Nat Rev Drug Discov 2016; 15(5):327.

31. Perico L, Benigni A, Remuzzi G. Should COVID-19 Concern nephrologists? Why and to what extent? The emerging impasse of angiotensin blockade. Nephron 2020; 1-9.

32. Chen Z, Zhang W, Lu Y, Guo C, Guo Z, Liao C, et al. From SARS-CoV to Wuhan 2019-nCoV Outbreak: Similarity of early epidemic and prediction of future trends. Cell Host Microbe; 2020.

33. Lai CC, Shih TP, Ko WC, Tang HJ, Hsueh PR. Severe acute respiratory syndrome coronavirus 2 (SARS-CoV-2) and corona virus disease-2019 (COVID-19): The epidemic and the challenges. Int J Antimicrob Agents 2020; 55:1-9.

34. Wang W, Tang J, Wei F. Updated understanding of the outbreak of 2019 novel coronavirus (2019-nCoV) in Wuhan, China. J Med Virol 2020; 94(4):441-7.

35. Lei J, Li J, Li X, Qi X. CT imaging of the 2019 novel coronavirus (2019-nCoV) pneumonia. Radiology 2020; 200236.

36. Jordan R, Adab P, Cheng K. Covid-19: risk factors for severe disease and death. BMJ (Clinical Research ed). 2020;368:1198-99.

37. Prevention CFDCA. Coronavirus Disease 2019 (COVID-19) 2020 [Available from:

http://www.cdc.gov/coronavirus/2019ncov/specific-groups/pe ople-at-higher-risk.html.

38. Holshue ML, DeBolt C, Lindquist S, Lofy KH, Wiesman J, Bruce $\mathrm{H}$, et al. First case of 2019 novel coronavirus in the United States. N Engl J Med 2020; 382:929-36.

39. Guan WJ, Ni ZY, Hu Y, Liang Wh, Ou CQ, He JX, et al. Clinical characteristics of coronavirus disease 2019 in China. N Engl J Med 2020; 382(18):1708-20.

40. Wang W, Xu Y, Gao R, Lu R, Han K, Wu G, et al. Detection of SARS-CoV-2 in different types of clinical specimens. JAMA 2020; 323(18):1843-44.

41. Wu Y, Guo C, Tang L, Hong Z, Zhou J, Dong X, et al. Prolonged presence of SARS-CoV-2 viral RNA in faecal samples. Lancet Gastroenterol Hepatol 2020; 5(5):434-35.

42. Kraay AN, Hayashi MA, Hernandez-Ceron N, Spicknall IH, Eisenberg MC, Meza R, et al. Fomite-mediated transmission as a sufficient pathway: a comparative analysis across three viral pathogens. BMC Infect Diseases 2018; 18(1):1-13.

43. Chen H, Guo J, Wang C, Luo F, Yu X, Zhang W, et al. Clinical characteristics and intrauterine vertical transmission potential of COVID-19 infection in nine pregnant women: A retrospective review of medical records. Lancet 2020; 395(10226):809-15.

44. Meng L, Hua F, Bian Z. Coronavirus Disease 2019 (COVID-19): Emerging and Future Challenges for Dental and Oral Medicine. J Dent Res 2020; 99(5):481-87.

45. Tellier R, Li Y, Cowling BJ, Tang JW. Recognition of aerosol transmission of infectious agents: a commentary. BMC Infect Dis 2019; 19(1):1-9.

46. Wong BC, Lee N, Li Y, Chan PK, Qiu H, Luo Z, et al. Possible role of aerosol transmission in a hospital outbreak of influenza. Clin Infect Dis 2010; 51(10):1176-83.

47. Kim UJ, Won EJ, Kee SJ, Jung SI, Jang HC. Case report Combination therapy with lopinavir/ritonavir, ribavirin and interferon- $\alpha$ for Middle East respiratory syndrome. Antiviral Therap 2016; 21:455-59.

48. Arabi YM, Alothman A, Balkhy HH, Al-Dawood A, AlJohani S, Al Harbi S, et al. Treatment of Middle East Respiratory Syndrome with a combination of lopinavir-ritonavir and interferon- $\beta 1 b$ (MIRACLE trial): Study protocol for a randomized controlled trial. Trials 2018; 19(1):1-8.

49. Jordan PC, Liu C, Raynaud P, Lo MK, Spiropoulou CF, Symons $\mathrm{JA}$, et al. Initiation, extension, and termination of RNA synthesis by a paramyxovirus polymerase. PLOS Pathogens 2018; 14(2):1-23.

50. Warren TK, Jordan R, Lo MK, Ray AS, Mackman RL, Soloveva $V$, et al. Therapeutic efficacy of the small molecule GS-5734 against Ebola virus in rhesus monkeys. Nature 2016; 531(7594):381-85.

51. Brown AJ, Won JJ, Graham RL, Dinnon III KH, Sims AC, Feng $\mathrm{JY}$, et al. Broad spectrum antiviral remdesivir inhibits human endemic and zoonotic deltacoronaviruses with a highly divergent RNA dependent RNA polymerase. Antiviral Res 2019; 169:1-10.

52. Cockrell AS, Yount BL, Scobey T, Jensen K, Douglas M, Beall $A$, et al. A mouse model for MERS coronavirus-induced acute respiratory distress syndrome. Nat Microbiol 2016; 2(2): 1-11.

53. Cai Q, Yang M, Liu D, Chen J, Shu D, Xia J, et al. Experimental Treatment with Favipiravir for COVID-19: An Open-Label Control Study. Engineering 2020; 1-7.

54. Yao X, Ye F, Zhang M, Cui C, Huang B, Niu P, et al. In vitro antiviral activity and projection of optimized dosing design of hydroxychloroquine for the treatment of severe acute respiratory syndrome coronavirus 2 (SARS-CoV-2). Cli Infect Dis 2020; 1-8.

55. Gautret P, Lagier J-C, Parola P, Meddeb L, Mailhe M, Doudier $B$, et al. Hydroxychloroquine and azithromycin as a treatment of COVID-19: results of an open-label nonrandomized clinical trial. Int J Antimicrobial Agents. 2020; $1-24$.

56. Mahendra Pal GB, Chaltu Desalegn, Venkataramana Kandi. 
Severe Acute Respiratory Syndrome Coronavirus-2 (SARSCoV-2): An Update. Cureus 2020; 12(3):1-13.

57. Caly L, Druce JD, Catton MG, Jans DA, Wagstaff KM. The FDAapproved Drug Ivermectin inhibits the replication of SARSCoV-2 in vitro. Antiviral Res 2020:1-4.

58. Shen C, Wang Z, Zhao F, Yang Y, Li J, Yuan J, et al. Treatment of 5 Critically III Patients With COVID-19 With Convalescent Plasma. JAMA 2020; 323(16):1582-89.

59. Cahill J. Potential COVID-19 therapeutics currently in development 2020 [Available from:

http://www.europeanpharmaceuticalreview.com/article/1158 42/pot ential-covid-19-therapeutics-currently-indevelopment/.

60. Bukhari N, Rasheed H, Nayyer B, Babar Z. Pharmacists at the frontline beating the COVID-19 pandemic. J Pharmaceut Pol Pract 2020; 13:8-8.

61. Ung COL. Community pharmacist in public health emergencies: Quick to action against the coronavirus 2019nCoV outbreak. Res Soc Adm Pharm 2020; 16(4):583-86.

62. Li H, Zheng S, Liu F, Liu W, Zhao R. Fighting against COVID-19: innovative strategies for clinical pharmacists. Res Soc Adm Pharm 2020; 1-6.

63. Khan Z, Muhammad K, Ahmed A, Rahman H. Coronavirus outbreaks: prevention and management recommendations. Drugs Ther Perspect 2020; 1-3.

64. Federation IP. COVID-19: Guidelines for Pharmacists and the Pharmacy Workforce: FIP; 2020 [Available from: http://www.fip.org/files/content/priority-areas/coronavirus/CO VID-19-Guidelines-for-pharmacists-and-the-pharmacyworkforce.pdf.

65. Su S, Wong G, Shi W, Liu J, Lai AC, Zhou J, et al. Epidemiology, genetic recombination, and pathogenesis of coronaviruses. Trends Microbiol 2016; 24(6):490-502.

66. Hamre D, Procknow JJ. A new virus isolated from the human respiratory tract. Proc Soc Exp Biolog Med 1966; 121(1): 190-93.

67. Van Der Hoek L, Pyrc K, Berkhout B. Human coronavirus NL63, a new respiratory virus. FEMS Microbiol Rev 2006; 30(5):760-73.

68. Woo PC, Lau SK, Chu CM, Chan KH, Tsoi HW, Huang Y, et al. Characterization and complete genome sequence of a novel coronavirus, coronavirus HKU1, from patients with pneumonia. J Virol 2005; 79(2):884-95.

69. McIntosh K, Dees JH, Becker WB, Kapikian AZ, Chanock RM. Recovery in tracheal organ cultures of novel viruses from patients with respiratory disease. Proc NatL Acad Sci U S A
1967; 57(4):933.

70. Peiris JS, Yuen KY, Osterhaus AD, Stöhr K. The severe acute respiratory syndrome. N Eng J Med 2003; 349(25):2431-41.

71. Zaki AM, Van BoheeD, Fouchier RA. Isolation of a novel coronavirus from a man with pneumonia in Saudi Arabia. $N$ Eng J Med 2012; 367(19):1814-20.

72. Linton NM, Kobayashi T, Yang Y, Hayashi K, Akhmetzhanov $A R$, Jung $S M$, et al. Incubation period and other epidemiological characteristics of 2019 novel coronavirus infections with right truncation: A statistical analysis of publicly available case data. J Clin Med 2020; 9(2):1-9.

73. Sohrabi C, Alsafi Z, O'Neill N, Khan M, Kerwan A, Al-Jabir A, et al. World Health Organization declares global emergency: A review of the 2019 novel coronavirus (COVID-19). Int J Surgery 2020; 76:71-6.

74. Organization WH. Coronavirus disease 2019 (COVID-19) Situation Report - 69: WHO; 2020 [Available from: http://www.who.int/docs/default-source/coronaviruse/situatio n-reports/20200329-sitrep-69-covid-19.pdf.

75. Duan Y-n, Qin J. Pre-and posttreatment chest CT findings: 2019 novel coronavirus (2019-nCoV) pneumonia. Radiology 2020; 295:21.

76. Roush SW, McIntyre L, Baldy LM. Manual for the surveillance of vaccine-preventable diseases. Atlanta. Centers Disease Control Prevent 2008; 4:1-9.

77. Franquet T. Imaging of pulmonary viral pneumonia. Radiology 2011; 260(1):18-39.

78. Lee KS. Pneumonia Associated with 2019 Novel Coronavirus: Can computed tomographic findings help predict the prognosis of the disease? Korean J Radiol 2020; 21(3): 257-58.

79. Zumla A, Hui DS, Perlman S. Middle East respiratory syndrome. Lancet 2015; 386(9997):995-1007.

80. Hansell DM, Bankier AA, MacMahon H, McLoud TC, Muller NL, Remy J. Fleischner Society: glossary of terms for thoracic imaging. Radiology 2008; 246(3):697-722.

81. Lauer SA, Grantz KH, Bi Q, Jones FK, Zheng Q, Meredith HR, et al. The Incubation Period of Coronavirus Disease 2019 (COVID-19) From Publicly Reported Confirmed Cases: Estimation and Application. Ann Intern Med 2020.

82. Dong L, Hu S, Gao J. Discovering drugs to treat coronavirus disease 2019 (COVID-19). Drug Discov Ther 2020; 14(1):58-60.

83. McCreary EK, Pogue JM, editors. Coronavirus Disease 2019 Treatment: A Review of Early and Emerging Options. Open Forum Infectious Diseases; 2020: Oxford University Press. 